\title{
Analisis kesalahan dalam menyelesaikan soal bentuk aljabar ditinjau dari taksonomi SOLO
}

\author{
Kunim Sriati ${ }^{*}$, Sudi Prayitno ${ }^{2}$, Nurul Hikmah², Laila Hayati ${ }^{2}$
}

\author{
1 Mahasiswa Pendidikan Matematika, FKIP, Universitas Mataram, Mataram \\ ${ }_{2}^{2}$ Pendidikan Matematika, FKIP, Universitas Mataram, Mataram
}

kunim.sriati@gmail.com

Diterima:17-12-2021; Direvisi: 28-12-2021; Dipublikasi: 30-12-2021

\begin{abstract}
The aim of this study is to describe the types of errors and their causes made by the seven grade students of SMPN 7 PUJUT in the academic year 2020/2021 in solving algebraic form questions based on the SOLO taxonomy level. This research is a qualitative descriptive study and the instruments used are test questions and interview guides. The subjects of this study were 32 grade seven students of SMPN 7 PUJUT who were selected using purposive sampling technique. After selecting one class, several students were selected according to the SOLO taxonomy level. The results showed that all students made the types of errors according to the basic objects of mathematics, namely fact errors, concept errors, operating errors, and principle errors. The results also showed that the questions given to 32 class seven students of SMPN 7 PUJUT obtained a percentage of the structural level of $31.25 \%$, the unistructural level of $37.5 \%$, the multistructural level of $21.9 \%$, the relational level of $9.38 \%$, and the extended abstract level is $0 \%$. The causes of students making mistakes in solving questions, namely: the cause of factual errors is that students do not understand the meaning of the questions which include what is known and asked and in determining the final result; the cause of misconceptions is that students do not understand the formula used; the cause of the operation error is that the students are not careful in calculating; and the cause of the principle error is that students do not understand the steps to solve it.
\end{abstract}

Keywords: error analysis; mathematical basic object errors; SOLO taxonomy

\begin{abstract}
Abstrak
Penelitian ini bertujuan untuk mendeskripsikan jenis-jenis kesalahan serta penyebabnya yang dilakukan oleh siswa kelas VII SMPN 7 Pujut tahun ajaran 2020/2021 dalam menyelesaikan soal bentuk aljabar berdasarkan level taksonomi SOLO. Penelitian ini adalah penelitian deskriptif kualitatif dan instrumen yang digunakan berupa soal tes serta pedoman wawancara. Subjek penelitian ini adalah 32 siswa kelas VII SMPN 7 Pujut yang dipilih menggunakan teknik purposive sampling. Setelah terpilih satu kelas kemudian dipilih beberapa siswa sesuai dengan level taksonomi SOLO. Hasil penelitian menunjukkan bahwa semua siswa melakukan jenis-jenis kesalahan menurut objek dasar matematika yaitu kesalahan fakta, kesalahan konsep, kesalahan operasi, dan kesalahan prinsip. Hasil penelitian juga menunjukkan bahwa soal-soal yang diberikan pada 32 orang siswa kelas VII SMPN 7 Pujut diperoleh persentase level prastruktural sebesar $31,25 \%$, level unistruktural sebesar 37,5\%, level multistruktural sebesar 21,9\%, level relasional sebesar $9,38 \%$, dan level extended abstract sebesar $0 \%$. Penyebab siswa melakukan kesalahan dalam menyelesaikan soal yaitu: penyebab kesalahan fakta adalah siswa tidak memahami maksud dari soal yang meliputi apa yang diketahui dan ditanyakan serta dalam menentukan hasil akhir; penyebab kesalahan konsep adalah siswa tidak paham dengan rumus yang digunakan; penyebab kesalahan operasi adalah siswa kurang teliti dalam perhitungan; dan penyebab kesalahan prinsip adalah siswa kurang memahami langkah-langkah penyelesaian.
\end{abstract}

Kata Kunci: analisis kesalahan; objek dasar matematika; taksonomi SOLO 


\section{PENDAHULUAN}

Pendidikan merupakan salah satu sarana strategis untuk meningkatkan kualitas suatu bangsa, karenanya kemajuan suatu bangsa dapat diukur dari kemajuan pendidikannya, salah satu pelajaran yang wajib dipelajari di dunia pendidikan mulai dari SD sampai SMA bahkan sampai jenjang perguruan tinggi adalah matematika (Turmuzi, M., Fitri, N. W., \& Subarinah, S., 2019). Matematika merupakan salah satu ilmu pengetahuan eksakta yang penting dan harus dikuasai oleh siswa (Aripin, U., \& Purwasih, R., 2017). Sedangkan menurut Patmi, S., Surmiyati., \& Kristayulita (2014), matematika adalah suatu alat untuk mengembangkan cara berfikir, hal ini dikarenakan selain dipelajari di setiap jenjang pendidikan, matematika juga sangat berperan penting dalam kehidupan sehari-hari. Salah satu tujuan pembelajaran matematika ialah agar siswa memiliki kemampuan pemahaman dalam memahami konsep matematika. Tanpa adanya kemampuan ini, siswa tidak akan mampu mengikuti pembelajaran matematika dengan baik, sehingga siswa akan sulit memahami dan menerapkan konsep yang telah diajarkan (Oktapiyanti., \& Amalia, R., 2020).

Hadi, S., \& Novaliyosi (2019) mengatakan bahwa saat ini dalam perkembangan pendidikan di Indonesia khususnya dalam pelajaran matematika masih rendah. Hal ini dapat dilihat dari hasil studi TIMSS (Trends in International Mathematics and Sains Study) pada tahun 2015 yang menempatkan Indonesia dalam bidang matematika diurutan ke-44 dari 49 Negara yang mengikuti tes dengan skor rata-rata 397. Hasil survey PISSA tahun 2018 yang menunjukkan bahwa hasil skor rata-rata prestasi matematika siswa Indonesia yaitu 379. Indonesia berada diperingkat ke-72 dari 78 negara yang berpartisipasi dalam PISA (Ramlah., \& Maharani, D., 2021). Sejalan dengan penelitian yang dilakukan oleh Sutriyono., \& Cahyani, C. A. (2018) bahwa kesulitan siswa dalam mempelajari matematika dikarenakan siswa tidak membangun sendiri tentang pengetahuan konsep-konsep matematika tanpa mengetahui makna yang terkandung pada konsep tersebut sehingga pada saat siswa menyelesaikan masalah matematika siswa sering melakukan kesalahan dan tidak menemukan solusi penyelesaian masalahnya.

Berdasarkan hasil observasi yang dilakukan oleh peneliti di SMP Negeri 7 Pujut, kenyataan dilapangan menunjukkan bahwa pengajaran di sekolah tersebut cenderung menekankan keterampilan dalam mengerjakan/menyelesaikan soal dibandingkan dengan pemberian konsep. Penanaman konsep hanya diberikan dalam waktu yang sangat singkat. Tingkat penguasaan siswa pada mata pelajaran matematika masih kurang, dimana nilai ketuntasan klasikal siswa masih dibawah 85\% dan nilai rata-rata setiap kelas masih dibawah Kriteria Ketuntasan Minimal (KKM) yang ditetapkan oleh sekolah yaitu 70 .

Menurut Asikin (2002) penerapan taksonomi SOLO untuk mengetahui kualitas respon dan analisis kesalahan sangatlah tepat, sebab taksonomi SOLO mempunyai beberapa kelebihan sebagai berikut, (1) taksonomi SOLO merupakan alat yang mudah dan sederhana untuk menentukan level respon siswa terhadap suatu pertanyaan 
matematika, (2) taksonomi SOLO merupakan alat yang mudah dan sederhana untuk pengkategorian kesalahan dalam menyelesaikan soal atau pertanyaan, (3) taksonomi SOLO merupakan alat yang mudah dan sederhana untuk menyusun dan menentukan tingkat kesulitan atau kompleksitas suatu soal atau pertanyaan matematika. Dalam taksonomi SOLO juga terdapat lima level dalam mengelompokkan tingkat kemampuan siswa. Lima level tersebut adalah: Prastruktural, Unistruktural, Multistruktural, Relasional, dan Exented Abstrack.

Menurut Legutko sebagaimana dikutip oleh Manibuy, R., Mardiyana., \& Saputro, D.R.S. (2014), sebuah kesalahan yang tidak terungkap yang berakar dari pikiran siswa, karena itu menjadi ancaman terbesar terhadap pembentukan pengetahuan siswa sehingga bermanfaat bagi siswa dan guru jika kesalahan tersebut bisa diungkapkan dan dibuktikan. Melalui analisis kesalahan akan diperoleh jenis dan penyebab kesalahan siswa dalam menyelesaikan soal materi bentuk aljabar.

\section{METODE PELAKSANAAN}

Jenis Penelitian ini menggunakan metode pendekatan penelitian kualitatif dengan jenis penelitian deskriptif. Metode kualitatif ini digunakan pada penelitian dengan kondisi objek yang alamiah bukan eksperimental (Indrawati, 2018). Dalam penelitian kualitatif deskriptif dimana peneliti ditempatkan sebagai Instrumen kunci (Junaidi., Turmuzi, M., Dasing, A. S. H., \& Baidowi, 2021). Subjek yang diteliti adalah siswa kelas VII E di SMPN 7 Pujut. Dalam pengambilan sampel digunakan teknik purposive sampling. Menurut Sugiyono (2018), bahwa purposive sampling yaitu teknik penentuan sampel dengan pertimbangan tertentu. Sebanyak 4 siswa yang menjadi sampel dengan pertimbangan berdasarkan pengkategorian yang dilakukan dengan cara diberikan tes kemampuan penyelesaian soal berdasarkan level taksonomi SOLO. Instrumen yang digunakan dalam penelitian ini adalah instrumen tes berupa soal bentuk aljabar dan pedoman wawancara. Waktu penelitian ini dilaksanakan pada bulan Februari semester genap tahun ajaran 2020/2021.

Jenis-jenis kesalahan siswa dapat diukur berdasarkan indikator respon siswa berdasarkan Taksonomi SOLO (Chick, H., 1998). Indikator respon siswa berdasarkan taksonomi SOLO dijelaskan pada Tabel 1 berikut.

Tabel 1. Indikator respon siswa berdasarkan taksonomi SOLO

\begin{tabular}{|c|c|c|c|}
\hline No. & Level Respon & Indikator & Penyebab \\
\hline 1 & Prastructural & $\begin{array}{l}\text { 1. Siswa menggunakan data atau proses } \\
\text { penyelesaian yang tidak benar } \\
\text { sehingga kesimpulan yang diperoleh } \\
\text { tidak tepat atau tidak relevan. } \\
\text { 2. Siswa hanya memiliki sedikit } \\
\text { informasi yang bahkan tidak saling } \\
\text { berhubungan, sehingga tidak } \\
\text { membentuk sebuah kesatuan konsep } \\
\text { sama sekali dan tidak mempunyai } \\
\text { makna apapun. }\end{array}$ & $\begin{array}{l}\text { 1. Kemampuan } \\
\text { pemahaman siswa } \\
\text { yang rendah pada } \\
\text { konsep materi bentuk } \\
\text { aljabar. } \\
\text { 2. Kesulitan siswa dalam } \\
\text { membaca informasi } \\
\text { pada soal. } \\
\text { 3. Siswa tidak terbiasa } \\
\text { menuliskan apa yang }\end{array}$ \\
\hline
\end{tabular}


3. Siswa belum bisa mengerjakan tugas yang diberikan secara tepat artinya siswa tidak memiliki keterampilan yang dapat digunakan dalam menyelesaikan tugas yang diberikan.

1. Siswa hanya menggunakan sedikitnya satu informasi dan menggunakan satu konsep atau proses penyelesaian.

2. Siswa menggunakan proses berdasarkan data yang terpilih untuk penyelesaian masalah yang benar tetapi kesimpulan yang diperoleh tidak relevan.

Relational

$5 \quad$ Extented abstract
1. Siswa menggunakan beberapa data/informasi tetapi tidak ada hubungan di antara data tersebut sehingga tidak dapat menarik kesimpulan yang relevan.

2. Siswa dapat membuat beberapa hubungan dari beberapa data/informasi tetapi hubunganhubungan tersebut belum tepat sehingga kesimpulan yang diperoleh tidak relevan.

1. Siswa menggunakan beberapa data/informasi kemudian mengaplikasikan konsep/proses lalu memberikan hasil sementara kemudian menghubungkan dengan data dan atau proses yang lain sehingga dapat menarik kesimpulan yang relevan.

2. Siswa mengaitkan konsep/proses sehingga semua informasi terhubung secara relevan dan diperoleh kesimpulan yang relevan.

1. Siswa menggunakan beberapa data/informasi kemudian mengaplikasikan konsep/proses lalu memberikan hasil sementara kemudian menghubungkan dengan data dan atau proses yang lain sehingga dapat menarik kesimpulan yang relevan dan dapat membuat generalisasi dari hasil yang diperoleh.

2. Siswa berpikir secara konseptual dan dapat melakukan generalisasi pada suatu domain/area pengetahuan dan pengalaman lain.

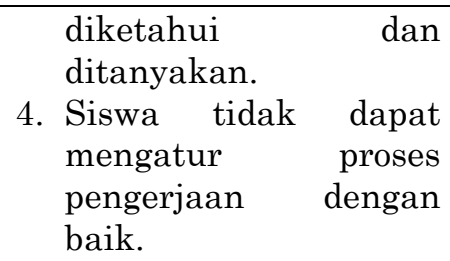

4. Siswa tidak dapat mengatur proses pengerjaan dengan baik.

1. Kurangnya pemahaman siswa terhadap langkahlangkah atau prosedur penyelesaian.

2. Kurang teliti dalam melakukan perhitungan.

3. Tidak meninjau kembali jawaban yang dikerjakan.

1. Kurangnya pemahaman siswa terhadap langkahlangkah atau prosedur penyelesaian.

2. Kurang teliti dalam melakukan penghitungan.

1. Sikap tergesa-gesa siswa dalam mengerjakan soal.

2. Siswa tidak memeriksa kembali jawaban yang dikerjakan 
Teknik analisis data yang digunakan pada penelitian ini adalah sebagai berikut.

\section{Tes Tertulis}

Tes merupakan suatu teknik yang digunakan dalam rangka melaksanakan kegiatan pengukuran, yang di dalamnya terdapat serangkaian pertanyaan atau latihan yang digunakan untuk mengukur keterampilan, pengetahuan, kecerdasan, kemampuan, atau bakat yang dimiliki oleh seseorang atau suatu kelompok (Prayitno, S., 2019). Dalam penelitian ini, data tes dari seluruh siswa yang melaksanakan tes tertulis disajikan dalam bentuk yang digunakan untuk menganalisis jawaban. Dari hasil kerja siswa ini peneliti membahas lembar jawaban yang merupakan hasil tes tertulis. Maksud kegiatan ini adalah untuk memperoleh data tentang jenis kesalahan yang dibuat siswa.

2. Wawancara Mendalam

Data wawancara diperoleh dari 4 responden yang telah ditentukan kemudian, setelah data tersebut dianalisis untuk mengetahui secara garis besar faktor-faktor yang menyebabkan siswa melakukan kesalahan dalam menyelesaikan soal matematika pada sub materi bentuk aljabar.

3. Reduksi Data

a) Empat siswa dengan tingkat respon yang berbeda menurut tingkatan taksonomi SOLO akan dipilih oleh peneliti,

b) Empat siswa yang terpilih selanjutnya diberikan tes yang kedua.

c) Dari hasil pekerjaan siswa, peneliti dapat menunjukkan kesalahan-kesalahan apa saja yang dilakukan subjek penelitian.

d) Hasil pekerjaan dari subjek penelitian merupakan data mentah kemudian ditransformasikan pada catatan sebagai bahan untuk wawancara.

e) Hasil wawancara disederhanakan menjadi susunan bahasa yang lebih baik, kemudian ditransformasikan ke dalam sebuah catatan. Kegiatan ini dilakukan dengan mengolah hasil wawancara menjadi data yang siap untuk digunakan.

4. Penyajian Data

Penyajian data dilakukan dengan menunjukkan dan menampilkan kumpulan data atau informasi yang sudah tersusun dan terkategori, sehingga memungkinkan suatu penarikan kesimpulan atau tindakan. Pada tahap ini, halhal yang dilakukan sebagai berikut.

a) Menyajikan hasil pekerjaan siswa, dalam hal ini siswa yang dimaksud adalah siswa yang dijadikan sebagai subjek penelitian, dimana hasil pekerjaan tersebut dijadikan bahan untuk wawancara.

b) Menyajikan transkrip wawancara dimana penyajiannya disusun dalam sebuah dialog.

c) Menyajikan hasil analisis yang berupa deskripsi kesalahan setiap subjek penelitian. 
5. Penarikan Kesimpulan

Penarikan kesimpulan dilakukan setelah semua data terkumpul. Kesimpulan ini mengenai deskripsi kesalahan dan faktor penyebab kesalahan siswa dalam menyelesaikan soal bentuk aljabar dari masing-masing tingkatan taksonomi SOLO yang dianalisis kesalahannya menggunakan analisis kesalahan objek dasar matematika.

\section{HASIL DAN PEMBAHASAN}

\subsection{Hasil}

Kualitas respon siswa kelas VII E SMPN 7 Pujut berdasarkan Taksonomi SOLO dapat dilihat pada Gambar 1 berikut.

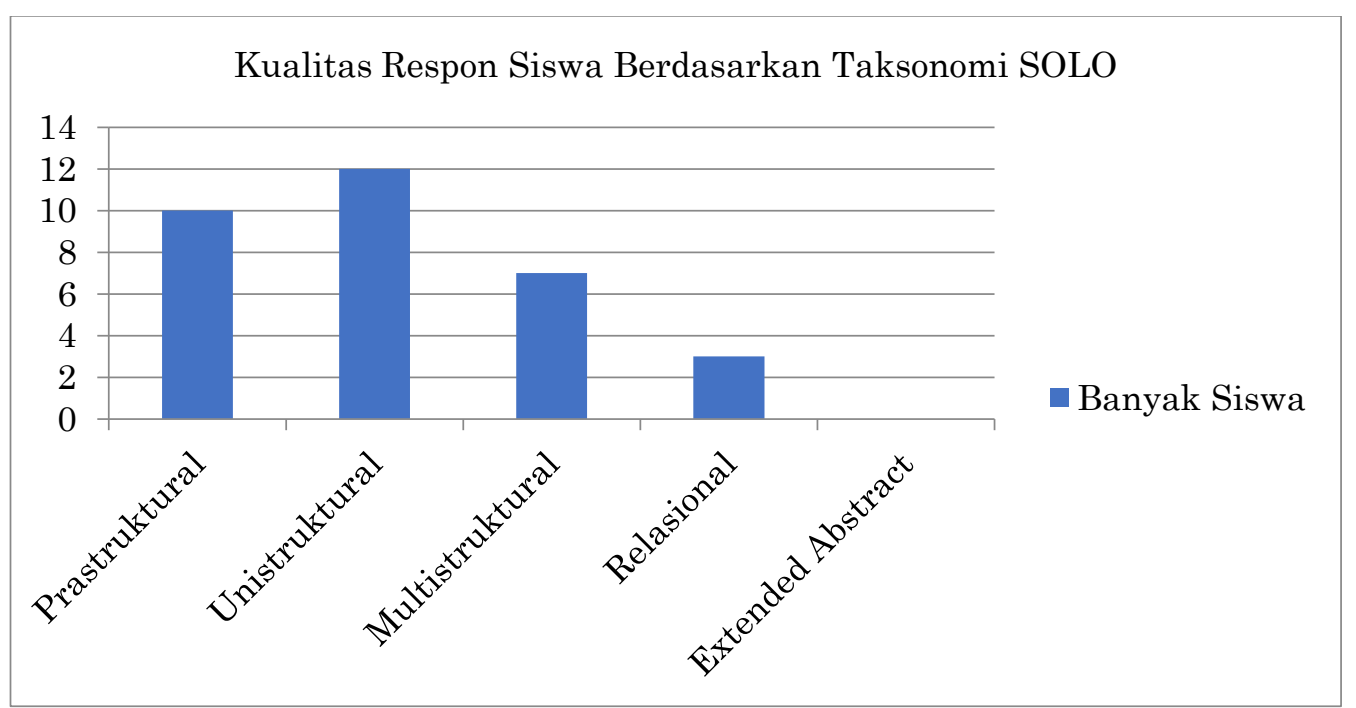

Gambar 1. Diagram kualitas respon siswa berdasarkan Taksonomi SOLO

Berikut hasil analisis kesalahan setiap level taksonomi SOLO berdasarkan analisis kesalahan objek dasar matematika.

\section{Siswa SP (Prastruktural)}

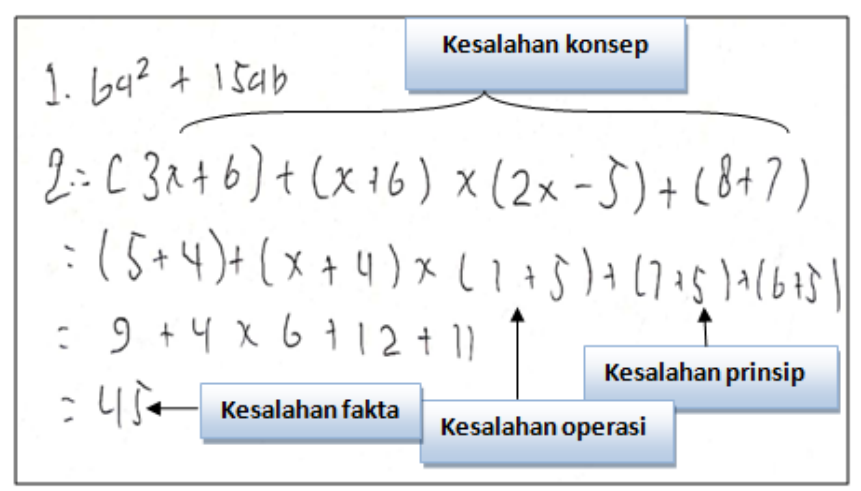

Gambar 2. Lembar jawaban siswa SP tes kedua

Berikut ringkasan wawancara dengan SP

P : "Apakah kamu tahu simbol-simbol yang ada pada soal nomor 1 ?" 
SP : :Tidak tahu Bu"

P : "Apakah kamu kesulitan dalam menentukan cara penyelesaian soal tersebut?"

$\mathrm{SP} \quad$ : "Iya Bu, karena ada "a" dan "b" nya Bu, itu juga yang membuat saya bingung dan tidak tahu cara menghitungnya"

P : :Bisakah kamu jelaskan apa yang diketahui dan apa yang ditanyakan pada soal nomor 2?"

SP : "Sisi terpendek $2 \mathrm{x}-5$, sisi terpanjang $3 \mathrm{x}+6$, sisi sisa $\mathrm{x}+6$, tentukan keliling segitiga"

P : "Terus kenapa kamu tidak menuliskan dilembar jawabanmu?"

S14 : "Lupa Bu"

P : "Dimana letak kesulitanmu dalam menjawab soal tersebut?"

SP : "Saya kesulitan dalam penjumlahan dan pengurangannya Bu karena ada simbol x"

P : :Apakah kamu tau rumus apa yang digunakan dalam soal tersebut?"

SP : "Tidak tau Bu".

Gambar 2 menunjukkan bahwa pada soal nomor satu dan dua, siswa SP salah dalam memaknai makna soal yaitu tidak mampu menuliskan apa yang diketahui dan apa yang ditanyakan dari soal, siswa tidak menuliskan rumus keliling segitiga pada soal nomor 2, siswa tidak mampu menuliskan langkah-langkah penyelesaian secara lengkap, siswa salah dalam perhitungan penjumlahan dan pengurangan sehingga jawaban akhir menjadi tidak relevan.

\section{Siswa SU (Unistruktural)}

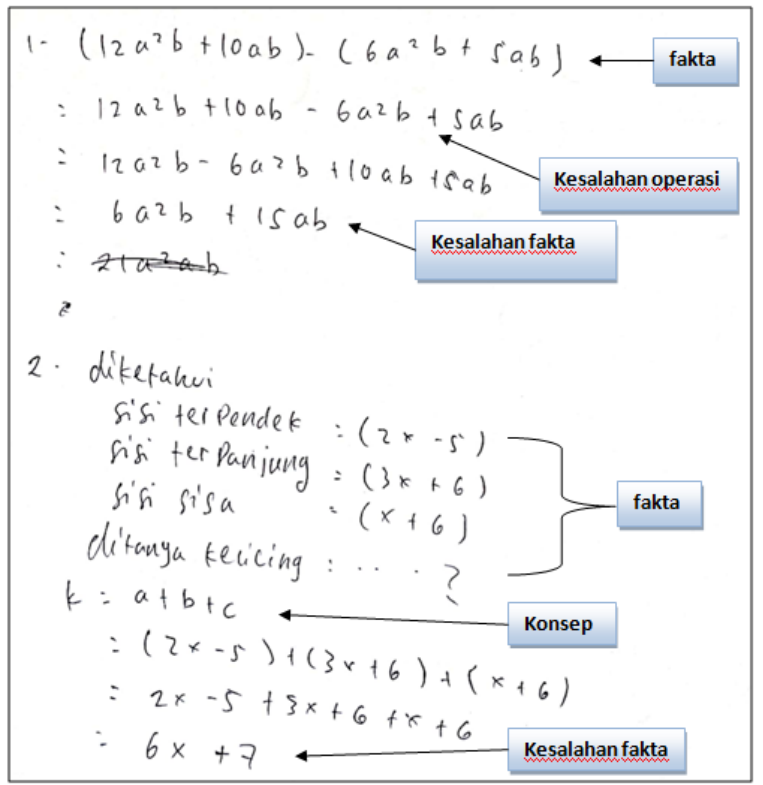

Gambar 3. Lembar jawaban siswa SU tes kedua

Berikut ringkasan wawancara dengan SU

$\mathrm{P} \quad$ : "Apakah kamu tahu simbol-simbol yang ada pada soal nomor 1?"

SU : "Tahu Bu"

$\mathrm{P} \quad$ : "Apakah kamu mengalami kesulitan dalam menentukan cara penyelesaian soal tersebut?"

SU : "Sedikit $\mathrm{Bu}$, pada penjumlahan dan pengurangannya karena terdapat variabelvariabel". 
P : "Bisakah kamu jelaskan apa yang diketahui dan ditanyakan pada soal nomor 2?"

SU : "Sisi terpendek $2 \mathrm{x}-5$, sisi terpanjang $3 \mathrm{x}+6$, sisi sisa $\mathrm{x}+6$, terus yang ditanyakan keliling segitiga Bu"

P : "Bisakah kamu sebutkan rumus yang akan digunakan pada soal tersebut?"

SU : "Rumusnya sisi + sisi + sisi"

$\mathrm{P} \quad$ : "Apakah kamu ada kesulitan dalam menghitung angka yang ada dalam soal tersebut?"

SU : "Sama seperti pada soal nomor $1 \mathrm{Bu}$ pada penjumlahan dan pengurangannya"

P : "Apakah kamu yakin jawaban akhirnya hanya seperti itu?"

SU : "Yakin Bu"

$\mathrm{P} \quad$ : "Apakah tidak ada langkah lain atau langkah lanjutan?"

SU : "Tidak ada Bu".

Gambar 3 menunjukkan bahwa pada soal nomor satu, siswa SU salah dalam mengalikan tanda operasi yang mengakibatkan kesalahan dalam menuliskan hasil akhir. Sedangkan untuk soal nomor dua, siswa SU sudah mampu memahami apa yang diketahui dan ditanyakan dari soal serta mampu menuliskan rumus yang akan digunakan, akan tetapi ada beberapa langkah penyelesaian yang tidak digunakan sehingga jawaban akhir menjadi tidak benar.

\section{Siswa SM (Multistruktural)}

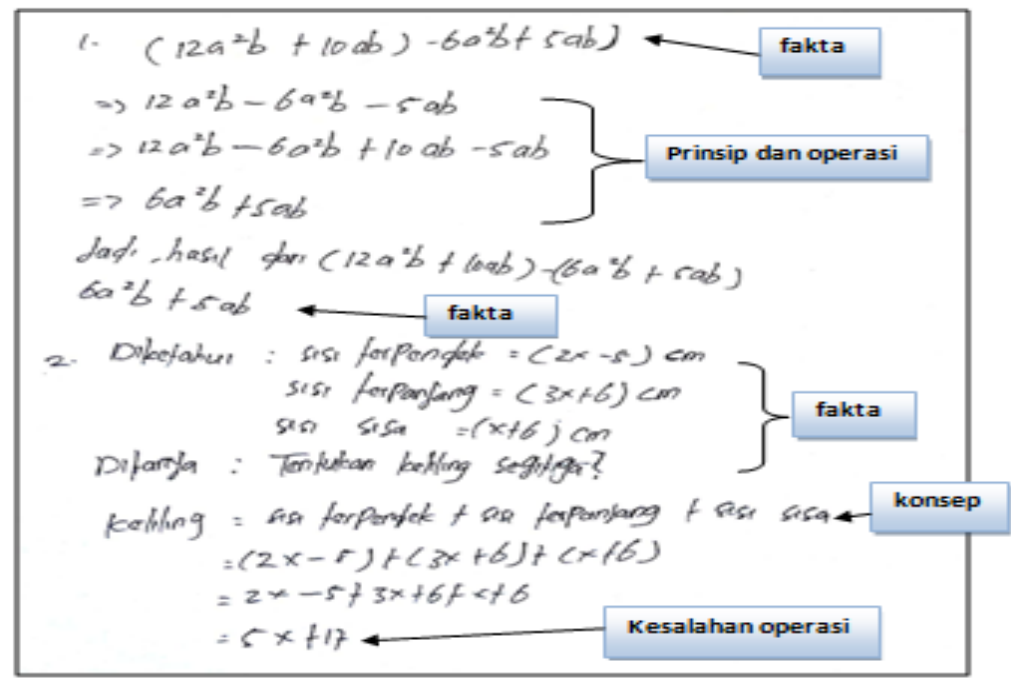

Gambar 4. Lembar jawaban siswa SM tes kedua

Berikut ringkasan wawancara dengan SM

$\mathrm{P} \quad$ : "Apakah kamu tahu simbol-simbol yang ada pada soal nomor 1?"

$\mathrm{SM} \quad$ : "Tahu Bu"

$\mathrm{P} \quad$ : "Apakah kamu ada kesulitan dalam menghitung angka pada soal tersebut?"

SM : "Tidak ada Bu"

$\mathrm{P} \quad$ : "Coba sebutkan apa yang diketahui dan ditanyakan pada soal nomor 2?"

SM : "Sisi terpendek $(2 \mathrm{x}-5) \mathrm{cm}$, sisi terpanjang $(3 \mathrm{x}+6)$, sisi sisa $(\mathrm{x}+6) \mathrm{cm}$, terus yang ditanyakan berapa keliling segitiga itu Bu"

$\mathrm{P} \quad$ : "Apakah kamu ada kesulitan dalam menghitung atau mengoperasikan angka dalam soal tersebut?"

SM : "Iya Bu"

$\mathrm{P} \quad$ : "Coba bacakan jawaban yang kamu peroleh"

SM : : $5 \mathrm{x}+17 "$ 
P : "Apakah kamu yakin dengan jawabanmu?"

SM : "Iya Bu"

$\mathrm{P} \quad$ : "Apakah kamu yakin jawabannya hanya sampai $5 \mathrm{x}+17$ ?, apakah tidak ada langkah yang dilupakan?"

SM : "Tidak ada, menurut saya jawabannya hanya sampai $5 x+17$ Bu".

Gambar 4 menunjukkan bahwa siswa SM sudah mampu menjawab soal nomor satu dengan benar. Sedangkan untuk soal nomor dua, siswa SM sudah mampu memahami apa yang diketahui dan ditanyakan dari soal serta mampu menuliskan rumus yang akan digunakan dengan tepat, akan tetapi melakukan kesalahan pada kesalahan operasi karena siswa tidak teliti dalam menjumlahkan dan ada beberapa langkah penyelesaian yang tidak digunakan sehingga hasil akhir menjadi tidak relevan.

\section{Siswa SR (Relasional)}

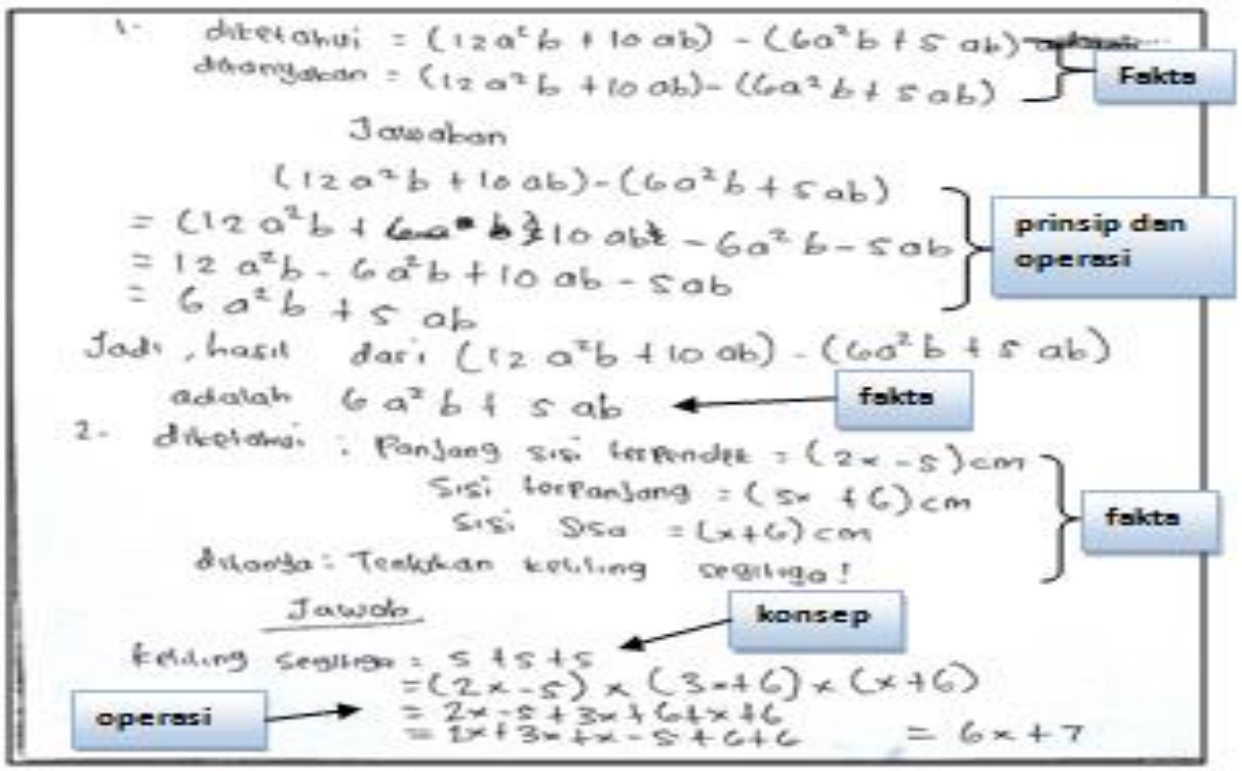

Gambar 5. Lembar jawaban siswa SR tes kedua

Berikut ringkasan wawancara dengan SR

P : "Apakah kamu tahu simbol-simbol yang ada pada soal 1?"

SR : "Tahu Bu, "a" dan "b" adalah variabel, 12 dan 10 koefisien"

$\mathrm{P} \quad$ :"Apakah kamu ada kesulitan dalam menghitung atau menyelesaikan soal tersebut?"

SR : "Tidak ada Bu"

$\mathrm{P} \quad$ : "Bisakah kamu jelaskan apa yang diketahui dan ditanyakan pada soal nomor 2?"

SR : "Panjang sisi terpendek $(2 \mathrm{x}-5) \mathrm{cm}$, panjang sisi terpanjang $(3 \mathrm{x}+6)$, panjang sisi sisa $(\mathrm{x}+6) \mathrm{cm}$, terus yang ditanyakan itu keliling segitiga $\mathrm{Bu}$ "

$\mathrm{P} \quad$ : "Apakah kamu ada kesulitan dalam mengoperasikan angka-angka pada soal tersebut?"

SR : "Tidak ada Bu"

P : :Apakah kamu yakin dengan langkah penyelesaian yang kamu gunakan?"

SR : "Yakin Bu"

P : "Dijawaban akhirmu ini masih ada nilai $\mathrm{x}$, apakah kamu yakin jawabanmu sudah selese sampai $6 x+7 \mathrm{Bu}$ " 
SR : "Saya hanya bisa menjawab sampai $6 x+7 \mathrm{Bu}$ ".

Gambar 5 menunjukkan bahwa siswa SR sudah mampu menjawab soal nomor satu dengan tepat. Sedangkan untuk soal nomor dua, siswa SR sudah mampu menuliskan apa yang diketahui dan ditanyakan dari soal, mampu menuliskan rumus segitiga dengan tepat serta melakukan operasi dengan benar, akan tetapi ada beberapa langkah-langkah penyelesaian yang tidak dilakukan yaitu mencari nilai $\mathrm{x}$ dengan menggunakan teorema pythagoras untuk menghasilkan nilai keliling segitiga yang relevan.

\subsection{Pembahasan}

Berdasarkan data yang telah diperoleh, maka disimpulkan kesalahan yang dilakukan siswa level Prastruktural yaitu; kesalahan fakta, konsep, prinsip, dan operasi. Kesalahan fakta meliputi kesalahan memahami makna soal yaitu tidak mampu mengidentifikasi atau menuliskan apa yang diketahui dan apa yang ditanyakan dari soal, dan jawaban akhir yang diberikan juga tidak benar. Kesalahan konsep meliputi siswa tidak mampu memahami konsep penjumlahan dan pengurangan bentuk aljabar karena siswa tidak paham konsep-konsep yang ada pada materi bentuk aljabar seperti variabel, koefisien, konstanta, suku sejenis dan suku tidak sejenis, serta tidak mampu menuliskan rumus keliling segitiga untuk soal nomor dua. Kesalahan prinsip meliputi siswa tidak mampu menuliskan langkah-langkah penyelesaian dengan lengkap dan benar. Sedangkan kesalahan operasi yaitu siswa melakukan kesalahan dalam perhitungan karena siswa tidak dapat membedakan suku sejenis dan tidak sejenis. Penelitian yang menguatkan yaitu hasil penelitian Asikin, M. (2002) yang menyimpulkan diantaranya bahwa pada level prastruktural peserta didik menolak memberi jawaban, menjawab secara cepat atas dasar pengamatan dan tanpa dasar yang logis.

Kesalahan yang dilakukan siswa level Unistruktural yaitu; kesalahan fakta karena tidak menuliskan jawaban akhir dengan benar, dan kesalahan operasi karena siswa sudah melakukan operasi hitung dengan tepat namun salah dalam menuliskan hasil operasi. Sedangkan untuk soal nomor dua siswa melakukan jenis kesalahan pada kesalahan fakta karena tidak tepat dalam menuliskan jawaban akhir dan kesalahan prinsip terlihat dari ada beberapa langkah penyelesaian yang tidak digunakan sehingga hasil akhir menjadi tidak relevan. Penelitian yang menguatkan yaitu hasil penelitian Manibuy, dkk. (2014) yang mengatakan bahwa kesalahan yang dilakukan siswa berkemampuan sedang (KMS) hanya mencapai level unistruktural dengan kesalahan dalam pemisalan variabel terkait dengan aturan-aturan dalam menyelesaikan persamaan kuadrat dan salah menuliskan jawaban akhir dari soal.

Pada level Multistruktural siswa tidak melakukan jenis kesalahan apapun pada soal nomor satu, siswa menjawab soal tersebut dengan baik dan benar. Sedangkan untuk soal nomor dua siswa melakukan jenis kesalahan prinsip karena ada beberapa langkah penyelesaian yang tidak digunakan sehingga hasil akhir menjadi tidak relevan dan 
kesalahan operasi karena terlihat jelas dalam menghitung operasi penjumlahan bentuk aljabar siswa tidak teliti dalam menjumlahkan sehingga jawaban yang diberikan tidak tepat. Penelitian yang menguatkan yaitu hasil penelitian Ekawati, R., Junaedi, I., \& Nugroho, S. E. (2013) yang mengatakan bahwa dalam level multistruktural ini, siswa menggunakan beberapa data/informasi tetapi tidak ada hubungan diantara data tersebut, siswa juga melakukan proses yang benar untuk satu tahap penyelesaian tetapi melakukan proses yang salah pada tahap berikutnya sehingga tidak dapat menarik kesimpulan yang relevan.

Subjek penelitian SR yang merupakan siswa level Relasional tidak melakukan jenis kesalahan apapun pada soal nomor satu, siswa menjawab soal tersebut dengan baik dan benar. Sedangkan untuk soal nomor dua siswa melakukan jenis kesalahan prinsip karena ada beberapa langkah lanjutan yang tidak dikerjakan sehingga jawaban akhir yang diberikan benar tapi kurang lengkap. Penelitian yang menguatkan yaitu hasil penelitian Pratiwi, N. D., \& Setyarsih, W. (2015) yang menyimpulkan bahwa pada level relasional diperoleh siswa sebesar $27,1 \%$ yang menunjukkan bahwa siswa dapat menghubungkan beberapa data atau informasi kemudian mengaplikasikan konsep dan membuat kesimpulan yang relevan. Hal ini dimaknai bahwa siswa yang mampu menyelesaikan soal pada tahap relasional adalah siswa yang mampu memahami, merencanakan, dan menyelesaikan soal dengan tepat serta mampu memberikan kesimpulan yang relevan.

Tidak terdapat siswa yang termasuk dalam kategori extended abstract, mengapa demikian karena tidak ada siswa yang mampu menjawab soal dengan kriteria extended abstract. Soal Extended abstract adalah soal yang menggunakan prinsip umum yang abstract atau hipotesis yang diturunkan dari informasi dalam teks soal. Dari data atau informasi yang diberikan itu masih dibutuhkan prinsip umum yang lebih abstrak sehingga mendapatkan informasi atau data baru. Dari data baru ini diperoleh penyelesaian akhir. Siswa dalam kategori ini harusnya sudah sangat menguasai materi dan memahami soal yang diberikan dengan sangat baik, sehingga siswa sudah mampu merealisasikan ke konsep-konsep yang ada. Hanya siswa yang tidak melakukan kesalahan yang tergolong dalam kategori ini.

\section{SIMPULAN}

Berdasarkan analisis hasil penelitian dapat disimpulkan sebagai berikut:

1. Kesalahan berdasarkan taksonomi SOLO siswa kelas VII SMP Negeri 7 Pujut adalah sebagai berikut:

a. Siswa level prastruktural ada sebanyak 10 orang siswa dengan persentase sebesar $31,25 \%$, jenis kesalahan yang dilakukan yaitu kesalahan fakta, kesalahan konsep, kesalahan prinsip, dan kesalahan operasi.

b. Siswa level unistruktural ada sebanyak 12 orang siswadengan persentase sebesar $37,5 \%$, jenis kesalahan yang dilakukan yaitu kesalahan fakta, kesalahan prinsip, dan kesalahan operasi. 
c. Siswa level multistruktural ada sebanyak 7 orang siswa dengan persentase sebesar 21,9\%, jenis kesalahan yang dilakukan yaitu kesalahan prinsip dan kesalahan operasi.

d. Siswa level relasional ada sebanyak 3 orang siswa dengan persentase sebesar $9,38 \%$, jenis kesalahan yang dilakukan yaitu kesalahan prinsip.

e. Level extended abstract diperoleh persentase sebesar 0\% atau tidak ada siswa yang berada pada kategori level extended abstract.

2. Adapun faktor penyebab kesalahan yang dilakukan siswa dalam menyelesaikan soal materi bentuk aljabar ditinjau dari taksonomi SOLO adalah sebagai berikut.

a. Penyebab kesalahan fakta pada siswa yaitu siswa tidak memahami maksud dari soal yang meliputi apa yang diketahui dan ditanyakan serta salah dalam menentukan hasil akhir.

b. Penyebab kesalahan konsep, siswa tidak paham konsep pada materi sehingga lupa dengan rumus yang digunakan.

c. Penyebab kesalahan prinsip, siswa kurang memahami prosedur atau langkahlangkah penyelesaian.

d. Penyebab kesalahan operasi, siswa kurang teliti dalam melakukan perhitungan.

\section{UCAPAN TERIMA KASIH}

Ucapan terimakasih disampaikan kepada semua pihak yang telah berperan dalam penelitian tentang keslalahan dalam menyelesaikan soal berdasarkan taksonomi SOLO di SMPN 7 Pujut hingga diterbitkannya tulisan ini.

\section{REKOMENDASI}

Diharapkan siswa mempelajari kembali materi bentuk aljabar, memperbanyak latihan soal, dan tidak sungkan bertanya pada guru bila ada materi yang belum dimengerti, hal ini dapat meminimalisir kesalahan yang dilakukan dalam mengerjakan soal bentuk aljabar. Kemudian hendaknya guru lebih menekankan pemahaman konsep secara jelas dan bukan hanya sekedar hafalan rumus sehingga kemampuan menyelesaikan soal semakin meningkat, serta lebih sering memberikan latihan soal. Selanjutnya bagi peneliti lain, diharapkan untuk melakukan penelitian dengan cara peneliti terlibat langsung saat proses belajar mengajar dan peneliti memberikan soal sesuai dengan kemampuan siswa dengan model pembelajaran yang menarik untuk membangkitkan semangat siswa dalam mengerjakan soal agar dapat solusi untuk menghindari kesalahan yang dilakukan siswa.

\section{REFERENSI}

Aripin, U., \& Purwasih, R. (2017). Penerapan Pembelajaran Berbasis Alternative Solutions Worksheet Untuk Meningkatkan Kemampuan Berpikir Kreatif. Aksioma: Jurnal Program Studi Pendidikan Matematika, 6(2), 225-233.

Asikin, M. (2002). Pengembangan Item Tes dan Interpretasi Respon Mahasiswa dalam Pembelajaran Geometri Analit Berpadu pada Taksonomi Solo.Laporan Penelitian: Lemlit UNNES Semarang. 
Chick, H. (1998). Cognition in the Formal Modes: Research Mathematics and The SOLO Taxonomy. Mathematics Education Research Journal, 10(2), 4-26.

Ekawati, R., Junaedi, I., \& Nugroho, S. E. (2013). Studi Respon Siswa Dalam Menyelesaikan Soal Pemecahan Masalah Matematika Berdasarkan Taksonomi SOLO. Unnes Journal of Mathematics Education Research, 2(2), 101-107.

Hadi, S., \& Novaliyosi. (2019). TIMMS Indonesia (Trends In International Mathematics and Science Study). Prosiding Seminar Nasional \& Call For Papers. (ISBN: 978-602-9250-39-8).

Indrawati. (2018). Metode Penelitian Kualitatif. Bandung: Refika Aditama.

Junaidi., Turmuzi, M., Dasing, A. S. H., \& Baidowi. (2021). Analisis Kesulitan Belajar Mahasiswa Secara Online (E-Learning) Selama Masa Pandemi Covid-19. Edukatif: Jurnal Ilmu Pendidikan, 3(3), 900-910.

Manibuy, R., Mardiyana., \& Saputro, D.R.S. (2014). Analisis Kesalahan Siswa dalam Menyelesaikan Soal Persamaan Kuadrat Berdasarkan Taksonomi SOLO pada Kelas X SMA Negeri 1 Plus di Kabupaten Nabire-Papua. Jurnal FKIP, 9(2), 933-945.

Oktapiyanti., \& Amalia, R. (2020). Analisis Kesalahan Siswa SMK dalam Menyelesaikan Soal Materi Persamaan Lingkaran Berdasarkan Taksonomi SOLO Plus Ditinjau dari Kemampuan Matematika Dasar. Jurnal Pembelajaran Matematika Inovatif, 3(1), 35-48.

Patmi, S., Surmiyati., \& Kristayulita. (2014). Analisis Kemampuan Kognitif dan Kemampuan Afektif Terhadap Kemampuan Psikomotor Setelah Penerapan KTSP. Beta, 7(1), 25-36.

Pratiwi, N. D., \& Setyarsih, W. (2015). Pengembangan Instrumen Evaluasi Berbasis Taksonomi Structure of the Observed Learning Outcome (SOLO) Untuk Menentukan Profil Kemampuan Siswa dalam Memecahkan Masalah Fluida Statis. Journal Inovasi Pendidikan Fisika (JIPF), 4(3), 45-49.

Prayitno, S. (2019). Evaluasi Pembelajaran Matematika. Mataram: Pustaka Ilmu.

Ramlah., \& Maharani, D. (2021). Deskripsi Kemampuan Komunikasi Matematis Siswa Dalam Menyelesaikan Permasalahan Segitiga dan Segiempat. Jurnal Pembelajaran Matematika Inovatif (JPMI), 4(2), 287-294.

Sugiyono. (2018). Metode Penelitian Kuantitatif. Bandung: Alfabeta.

Sutriyono., \& Cahyani, C. A. (2018). Analisis Kesalahan Siswa dalam Menyelesaikan Soal pada Materi Operasi Penjumlahan dan Pengurangan Bentuk Aljabar Bagi Siswa Kelas VII SMP Kristen 2 Salatiga. Jurnal Teori dan Aplikasi Matematika, 2(1), 26-30.

Turmuzi, M., Fitri, N. W., \& Subarinah, S. (2019). Analisis Kesalahan Newman dalam Menyelesaikan Soal Cerita Materi Turunan pada Siswa Kelas XII. Mandalika Mathematics and Education Journal, 1(2), 66-73. 